\title{
LEGALISASI EKONOMI SYARIAH DALAM KEHIDUPAN BERBANGSA DAN BERNEGARA
}

\author{
Zainal Arif \\ zarif1979@yahoo.com \\ (Fakultas Agama Islam, Universitas Muhammadiyah Tangerang)
}

\begin{abstract}
Abstrak;
Perkembangan, Pelembagaan dan legalisasi ekonomi Syariah di Indonesia dapat dikatakan sangat pesat setelah mendapat dukungan pemerintah dalam bentuk regulasi ekonomi yang berprinsipkan pada prinsip-prinsip ekonomi syariah. Perkembangan pesat tersebut dapat terlihat dalam berbagai bidang ekonomi yang menerapkan sistem ekonomi syariah, seperti perbankan Syariah, asuransi Syariah, sukuk (Obligasi syariah), pasar modal Syariah, keuangan publik, dan lain-lain. Fakta berbeda perkembangan dan pertumbuhan praktik ekonomi syariah dapat dilihat dalam kurun waktu di mana pemerintah belum berpihak pada ekonomi syariah, yaitu sebelum reformasi. Realitas yang demikian, memberikan harapan besar yang menumbuhkan optimisme bagi umat Islam untuk terus berupaya mengembangkan ekonomi syariah di Indonesia, terlebih lagi dukungan pemerintah yang diwujudkan dalam berbagai regulasi dan political will semakin nyata mendukung pengembangan ekonomi syariah di Indonesia. Diharapkan penerapan politik ekonomi syariah yang lebih luas akan mempercepat terwujudnya tatanan ekonomi yang berkeadilan dan menyejahterakan di bumi nusantara. Sehingga apa yang dicita- citakan oleh para pendiri bangsa bisa terwujud.
\end{abstract}

\section{Kata Kunci: Legalisasi, Ekonomi, Syariah, Bangsa dan Negara}

\begin{abstract}
;
The development, institutionalization and legalization of the Sharia economy in Indonesia can be said to be very rapid after receiving government support in the form of economic regulation based on Islamic economic principles. This rapid development can be seen in various economic fields that implement a sharia economic system, such as Islamic banking, Islamic insurance, sukuk (Islamic bonds), Islamic capital market, public finance, and others. Different facts on the development and growth of sharia economic practices can be seen in a period where the government has not sided with the sharia economy, namely before reform. This reality provides great hope which will foster optimism for Muslims to continue to strive to develop the Islamic economy in Indonesia, especially government support embodied in various regulations and political will to increasingly support the development of the Islamic economy in Indonesia. It is hoped that the wider application of Islamic political economy will accelerate the realization of a just and prosperous economic order in the archipelago. So that what the founders of the nation aspired to be realized.
\end{abstract}

Keywords: Legalization, Economy, Sharia, Nation and State

\section{A. Pendahuluan}

Perkembangan dan legalisasi

ekonomi syariah dalam berbagai bidangnya beberapa terakhir menunjukkan pertumbuhan yang sangat signifikan. Hal ini berbeda sekali dengan perkembangan aplikasi ekonomi Syariah sebelum reformasi. Hal ini dapat dilihat dari jumlah 
institusi perbankan Syariah yang tumbuh dan berkembang pada dua kurun periode tersebut. Pada tahun sebelum reformasi hanya ada 2 BUS, 1 UUS, dan 79 BPRS dengan aset masih berkisar 1,5 triliun. $^{1}$ Sedangkan pada kurun waktu 2000 - 2010 hingga bulan Januari 2011, jumlah institusi perbankan Syariah telah menjadi 11 BUS, 23 UUS, 151 BPRS dengan aset mencapai lebih dari 95 Trilyun. $^{2}$

Fenomena ini sangat menarik untuk dicermati, mengingat perbedaan level perkembangan ekonomi syariah antara dua kurun waktu tersebut sangat jauh berbeda. Hal ini menimbulkan pertanyaan yang perlu penjelasan, apakah karena faktor politik umat islam terhadap ekonomi pemerintah yang pada kurun waktu pasca reformasi lebih mengakomodir sistem ekonomi syariah sehingga menggairahkan para pihak untuk lebih concern dalam mengembangkan ekonomi syariah ataukah karena faktor lain. Oleh karena itu, perlu dilakukan kajian mengenai hubungan negara dan ekonomi syariah pasca reformasi . Kajian itu penting karena hasilnya dapat dijadikan sebagai landasan akademis untuk menerapkan kebijakan dan regulasi ekonomi yang lebih progresif dan apresiatif terhadap ekonomi syariah agar tujuan pembangunan ekonomi di Indonesia dapat segera terwujud.

\section{B. Hubungan Ekonomi, Islam dan Negara}

Islam adalah sistem yang menyeluruh, mencakup seluruh sisi kehidupan. Ia adalah negara dan tanah air, pemerintah dan umat, akhlak dan kekuatan, kasih sayang dan keadilan, peradaban dan undang-undang, ilmu dan peradilan, materi dan kekayaan alam, penghasilan dan

\footnotetext{
${ }^{1}$ Statistik Perbankan Syariah (2003), Jakarta: Biro Perbankan Syariah BI, p. 2

${ }^{2}$ Statistik Perbankan Syariah (Januari 2011), Jakarta: Direktorat Perbankan Syariah BI, p. 6
}

kekayaan, jihad dan dakwah, pasukan dan pemikiran. Ia adalah aqidah yang lurus, ibadah yang benar, tidak kurang tidak lebih. ${ }^{3}$ "...Pada hari ini telah Kusempurnakan untuk kamu agamamu, dan telah Kucukupkan kepadamu nikmat$\mathrm{Ku}$, dan telah Kuridhai Islam itu jadi agama bagimu..." (QS. Al Maidah: 3)

Islam sebagai konsep atau sistem hidup bersifat integratif (kesatuan) dan komprehensif (sempurna), Ia mengintegrasikan semua aspek kehidupan manusia di dunia, baik dalam kehidupan pribadi maupun interaksi kolektif. Ia juga meliputi semua sisi detil kehidupan (komprehensif), sehingga mencerminkan kelengkapan dan kesempurnaan Islam sebagai sebuah sistem atau konsep hidup. Imam Hasan Al Banna dengan sangat jelas menerangkan posisi Islam bagi kehidupan dalam karya besarnya Majma'atu Rasail (Risalah Pergerakan) ${ }^{4}$. Al Banna menggambarkan bahwa Islam meliputi semua aspek kehidupan, dimana Islam adalah negara dan tanah air, pemerintah dan ummat, moral dan kekuatan, kasih sayang dan keadilan, peradaban dan undang-undang, ilmu pengetahuan dan hukum, materi dan kekayaan alam, penghasilan dan kekayaan, jihad dan dakwah, pasukan dan pemikiran, sebagaimana juga ia adalah akidah yang murni dan ibadah yang benar, tidak kurang dan tidak lebih.

Dalam pembahasan sistem ekonomi syariah ini, Islam ditempatkan sebagai semesta sistem yang didalamnya terdapat subsistem-subsistem yang mengatur segala jenis aktivitas manusia dalam kehidupannya. Salah satunya adalah sistem

\footnotetext{
${ }^{3}$ Yusuf Qardhawi, Peran Nilai dan Moral dalam Perekonomian Islam, (Jakarta:Robbani Press. 2001).h.57

${ }^{4}$ Hasan Al Banna, Risalah Pergerakan, (Jakarta:Intermedia.1997), h.116
} 
ekonomi sebagai anggota sistem dalam semesta sistem hidup Islam.

Dalam falsafah keilmuan Islam, dapat digambarkan posisi ekonomi syariah $^{5}$ berada dalam ruang lingkup pembahasan ilmu syariah. Aktivitas ekonomi diklasifikasikan dalam pembahasan muammalah jika dirujuk dalam bahasan keilmuan Islam. Dan dalam pembahasan fikih muammalah biasanya lebih pada pembahasan kaidah-kaidah atau prinsip-prinsip umum bermuammalah yang diatur oleh nilai dan aturan Islam. Imam Al Ghazali $^{6}$ menyebutkan bahwa tujuan dari Syariah adalah meningkatkan kesejahteraan (welfare) seluruh manusia, melalui perlindungan agama (dien), diri manusia (nafs), akal (aql), keturunan (nasl) dan harta (maal). Definisi Al Ghazali ini sangat jelas menggambarkan fungsi sistem ekonomi yang mengambil syariah sebagai paradigmanya, dan tentu saja lebih menjelaskan hirarki keilmuan ekonomi syariah berkaitan dengan inti idiologi Islam.

Dalam ayat di atas Allah SWT secara implisit menegaskan bagaimana aktivitas penggalian ilmu tidak boleh terlepas dari nilai-nilai ilahiyah. Sehingga pengkajian ilmu bukan hanya bertujuan melakukan transfer ilmu (knowledge) tapi juga ada transfer nilai moral (value). Di samping itu sebenarnya ilmu yang benar sepatutnya memang tak memisahkan pengetahuan dengan nilai moral. Dalam ilmu sebaiknya mengandung dua unsur penting tersebut, sehingga tak ada ilmu yang dapat disebut ilmu yang bebas nilai.

Ekonomi islam atau lebih dikenal dengan sebutan ekonomi syariah yang kini semakin tumbuh dan berkembang begitu

\footnotetext{
${ }^{5}$ Dalam penyebutan ekonomi syariah, akan menyebutkan ekonomi syariah, yang pada dasarnya sama secara subtansi, yang mana istilah ekonomi syariah hanya trend di indonesia

${ }^{6}$ Imam Al Ghazali, Ihya Ulumuddin: Jilid 2, Asy Syifa, Jakarta, 1990.
}

signifikan, tentunya keadaan ini membawa kabar gembira bagi umat Islam. Tidak dapat dipungkiri bahwa perkembangan ekonomi syariah melaju begitu cepat. Perkembangan ekonomi syariah tidak hanya terjadi di Indonesia akan tetapi hampir di sebagian besar negara di Asia, Afrika, Australia, dan Amerika. Bahkan bisa dibilang Indonesia telah jauh tertinggal jika dibandingkan negara-negara lain di Asia, Afrika, dan Eropa. Hal ini tentu saja tidak terlepas dari peran serta masyarakatnya dalam berkontribusi dan berpartisipasi dalam mengembangkan ekonomi syariah. Di samping itu yang tidak bisa abaikan adalah peran serta pemerintah, terutama dalam menciptakan regulasi. Dengan demikian wajar bila perkembangan ekonomi syariah di negaranegara tersebut lebih agresif jika dibandingkan dengan Indonesia. Di indonesia perkembangan ekonomi syariah dapat dikatakan baru memulai masanya bila dibandingkan dengan perkembangan ekonomi konvensional yang sudah jauh berkembang. Namun di masa inilah justru ekonomi syariah akan menjadi perintis yang akan membawa perekonomian rakyat jauh lebih baik. Karena jelas bahwa ekonomi syariah adalah ekonomi yang berlandaskan Al-Qur'an dan Hadis Nabi saw. Sebagai bukti riil di masyarakat, perkembangan ekonomi syariah ditunjukan dengan munculnya lembaga-lembaga ekonomi syariah baik itu Bank Syariah, Asuransi Syariah, BPR Syariah, BMT, Tabung Wakaf, dan lain sebagainya. Dan yang baru-baru ini adalah semakin banyaknya Bank umum/konvensional yang membuka divisi syariah atau yang sering disebut dengan Unit Usaha Syariah (UUS) yang dapat melayani transaksi berdasakan akad-akad syariah. Tentunya ini merupakan angin segar bagi pertumbuhan ekonomi syariah khususnya di industri keuangan. Melihat ekonomi syariah di Indonesia berkembang dengan pesat, 
terutama di sektor industri keuangan, ternyata fenomena ini diikuti di sektor/bidang pendidikan. Sudah dipastikan keadaan ini akan sangat mendukung dan membantu percepatan laju pertumbuhan ekonomi syariah. Saat ini hampir sebagian besar perguruan tinggi baik negeri maupun swasta telah membuka jurusan/studi ekonomi syariah dan kajian atau diskusi-diskusi mengenai ekonomi syariah, seperti UI (Univesitas Indonesia), IPB (Institut Pertanian Bogor),UIN (Univesrsitas Islam Negeri), IAIN (Institut Agama Islam Negeri), ITB (Institut tehnologi Bandung), UGM (Univesitas Gajah Mada), UNHAS ( Universitas hasanuddin), Universitas Trisakti, dan Sekolah Tinggi Ilmu Ekonomi lainnya.

Realita di atas perlu disadari bersama bahwa ekonomi syariah mempunyai cakupan yang luas, tidak hanya sekedar yang berskala makro-kelembagaan dengan model perbankan syariah ataupun asuransi syariah, tetapi lebih jauh dari itu implementasi ekonomi syariah dapat terlaksana melalui kesadaran akan perilaku individu di keluarga untuk melaksanakan ajaran Islam secara kaffah, khususnya yang berkaitan dengan nilai-nilai ekonomi. Selain dari hal di atas, yang perlu dicermati adalah bahwa kesadaran individu masyarakatnya yang mayoritas Islam akan implementsi ekonomi syariah masih kurang. Di sisi lain yang perlu dicermati juga adalah masalah regulasi dari pemerintah mengenai ekonomi syariah yang sampai sekarang belum terealisasi. Realita ini diharapkan bisa berubah yang membawa ke arah yang lebih baik menuju perekonomian rakyat jauh lebih baik, sehingga tercipta kehidupan yang adil dan sejahtera. Dan inilah yang menjadi karakter ilmu ekonomi syariah. Ekonomi Syariah bahkan menempatkan nilai moral (akidah dan akhlak) sebagai asumsi dasar utama dari ilmu dan sistem ekonomi yang dibangun. Efektifitas dan optimalisasi sistem ekonomi syariah ini sangat ditentukan oleh tingkat nilai moral Islam yang ada pada pelaku-pelaku ekonomi.

Penelitian mengenai hubungan antara Agama dan ekonomi yang telah dilakukan. Max Weber yang dipublikasikan dalam buku "The Protestant Ethic and the Spirit of Capitalism" menjelaskan bahwa Etika Protestan dan hubungannya dengan semangat kapitalisme rupanya suatu teori yang sangat menarik perhatian para ilmuwan sosial hingga sekarang ${ }^{7}$. Menurut pengamatan Weber di kalangan Protestan sekte Calvinis, kerja keras adalah suatu keharusan bagi setiap manusia untuk mencapai kesejahteraan. Kerja keras ini merupakan panggilan rohani untuk mencapai kesempurnaan hidup, sehingga mereka dapat hidup lebih baik secara ekonomi. Dengan bekerja keras serta hidup hemat dan sederhana para pengikut ajaran Calvin tidak hanya hidup lebih baik tetapi mereka mampu pula menfungsikan diri mereka sebagai wiraswasta yang tangguh dan menjadikan diri mereka sebagai tulang punggung dari sistem ekonomi kapitalis ${ }^{8}$. Tidak hanya sekte Calvinis yang memberikan motivasi orang untuk bergerak dalam bidang ekonomi, hampir semua agama memberikan dorongan untuk bekerja keras, berdagang atau berbisnis.

\section{Perkembangan Ekonomi Syariah di Indonesia}

Di Indonesia, pendirian bank yang beroperasi berdasarkan prinsip Syariah ${ }^{9}$

\footnotetext{
${ }^{7}$ Abdullah, Taufik (ed.), 1982. Agama, Etos Kerja dan Perkembangan Ekonomi. Jakarta: LP3ES .h. 4

${ }^{8}$ Mubyarto dkk.1991. Etos Kerja dan Kohesi Sosial. (Yogyakarta: Aditya Media).h.2

${ }^{9}$ Lembaga-lembaga keuangan yang didirikan dengan berlandaskan prinsip syariah mempunyai dua tujuan utama, yaitu: (1) Membangun sosioekonomi yang berlandaskan keadilan dan menganggap aktivitas ekonomi sebagai cara mencapai tujuan dan bukannya tujuan itu sendiri. (2) Islam menekankan persoalan perkembangan
} 
pertama kali bermula pada tahun 1991 dengan pendirian Bank Muamalat Indonesia (BMI). ${ }^{10}$ Walaupun didirikan pada 1991 tetapi baru beroperasi pada tahun 1992. Itupun belum memakai nama bank Syariah tetapi sebagai bank bagi hasil, karena memang belum ada payung hukum yang menjadi naungan berdirinya bank Syariah di Indonesia. Dengan demikian, Indonesia tertinggal 9 tahun dari Malaysia dalam memulakan praktik ekonomi syariah, khususnya dalam perbankan Syariah.

Dalam kurun waktu tahun 19911998, perkembangan bank Syariah di Indonesia dapat dikatakan lambat." Ini disebabkan karena aspek perundangan. Undang-Undang (UU) No. 7 Tahun 1992 tentang Perbankan dan Peraturan Pemerintah (PP) No. 72 Tahun 1992 yang merupakan salah satu peraturan pelaksanaan undang-undang tersebut, dalam pasal 6 menentukan bahwa bank

ekonomi dan melihatnya sebagai bagian yang terpenting daripada masalah-masalah lain yang lebih besar. Pertumbuhan ekonomi tidak dapat dipisahkan dari perkembangan manusia secara total. Fungsi utama Islam adalah untuk memandu perkembangan manusia ke arah landasan yang benar. Saad al-Harran (1995), Leading Issues in Islamic Banking and Finance. Selangor: Pelanduk Publication Sdn. Bhd., p. viii.

$$
{ }^{10} \mathrm{M} \text { Dawam Rahardjo }
$$

(2004), "Menegakkan Syariat Islam di Bidang Ekonomi", kata pengantar Buku Adiwarman Karim, Bank Islam, Analisis Fiqh dan Keuangan. Jakarta: PT RajaGrafindo Persada, p. xviii-xix; Heri Sudarsono (2004), Bank dan Lembaga Keuangan Syariah; Deskripsi dan Ilustrasi. Yogyakarta: EKONISIA, p. 31. Lihat pula Iman Hilman (2003), "Transformasi Perbankan Syariah, Suatu Keharusan", dalam Irwan Kelana et al. (eds.), Perbankan Syariah Masa Depan. Jakarta: PT Senayan Abadi, p. 3.

${ }^{11}$ Sofyan S. Harahap dan Yuswar Z. Basri (2004), "The History and Development of Islamic Banking in Indonesia, 1990-2002", dalam Bala Shanmugan et al. (eds.), Islamic Banking: An International Perspective. Serdang: Universti Putra Malaysia Press, p. 39. umum dan Bank Perkreditan Rakyat (BPR) yang kegiatannya berasaskan prinsip bagi hasil, tidak diperkenankan melakukan usaha yang tidak berasaskan prinsip bagi hasil. Begitu juga sebaliknya. Ini bermakna, tidak ada peluang untuk membuka Syariah windows di bank konvensional. ${ }^{12}$ Peraturan itu menjadi penghalang bagi berkembangnya bank Syariah, karena jalur pertumbuhan bank Syariah hanya melalui perluasan kantor bank Syariah yang telah ada atau pembukaan bank Syariah baru yang membutuhkan dana sangat besar..$^{13}$

Di sisi lain, aturan lebih komprehensif yang mengatur tentang bank Syariah masih sangat terbatas, sehingga dalam banyak hal bank Syariah harus patuh pada peraturan perbankan konvensional. Oleh karena itu, manajemen BMI cenderung untuk meniru produk dan jasa perbankan konvensional yang kemudian "diislamkan". Ini menyebabkan jenis produk dan jasa yang ditawarkan oleh BMI terbatas, sebab tidak semua produk dan jasa bank konvensional bisa "diislamkan". Akibatnya tidak semua keperluan masyarakat dapat dipenuhi. ${ }^{14}$

Pada saat bersamaan, pada tahun 1992-an tersebut, berkaca pada berhasilnya pendirian BMI sebagai bank yang menganut prinsip Syariah, telah mengilhami kesadaran masyarakat untuk mengamalkan ekonomi Syariah, sehingga sejak itu mulai didirikan lembaga keuangan Syariah mikro yaitu Bank Perkreditan Rakyat Syariah (BPRS, kini singkatannya menjadi Bank Pembiayaan

\footnotetext{
${ }^{12}$ Muhammad Amin Suma (2003), “Jaminan Perundang-undangan Tentang Eksistensi Lembaga Keuangan Syariah di Indonesia", Jurnal alMawarid, Edisi X, p. 9.

${ }^{13}$ Muhammad Syafi'i Antonio (2001), Bank Islam dari Teori ke Praktek. Jakarta: Gema Insani Press, pp. 25-26. 10.
} 
Rakyat Syariah) dan Baitul Mal Wattamwil (BMT). ${ }^{15}$

Istilah BMT berasal dari dua suku kata yaitu bayt al-mal dan bayt al-tamwil. Istilah bayt al-mal berasal dari kata bayt dan al-mal. Bayt artinya bangunan atau rumah, sedangkan al-mal berarti harta benda dan kekayaan. Jadi secara etimologis (harfiyyah) atau segi bahasa berarti, baytul mal berarti rumah kekayaan. Namun demikian kata bayt al-mal biasa diartikan sebagai perbendaharaan (umum atau negara). ${ }^{16}$ Sementara bayt al-tamwil berasal dari kata bayt artinya rumah, dan al-tamwil merupakan bentuk masdar yang artinya pengumpulan harta. Jadi bayt altamwil dapat diartikan sebagai rumah pengumpulan harta atau dapat diidentikkan dengan bank pada zaman modern ini. Dalam konteks Indonesia, BMT memiliki makna yang khas, yaitu lembaga keuangan mikro Syariah untuk membantu usaha ekonomi rakyat kecil, yang beranggotakan perorangan atau badan hukum, yang dijalankan berdasarkan prinsip Syariah dan prinsip koperasi. Pada akhir 2010, jumlah BMT di Indonesia mencapai 4000an buah. ${ }^{17}$

Pada tahun 1998, pemerintah mengundangkan Undang-Undang No. 10 Tahun 1998 tentang perubahan terhadap Undang-Undang No. 7 Tahun 1992 tentang perbankan, yang di dalamnya sudah memuat tentang operasi perbankan berdasarkan prinsip Syariah. Setahun

${ }^{15}$ Adiwarman Karim (2004), Bank Islam, Analisis Fiqh dan Keuangan. Jakarta: PT RajaGrafindo Persada, pp. 24-25; Heri Sudarsono (2004), op.cit., pp. 32 dan 83-84.

${ }^{16}$ Secara fiqhiyyah, bayt al-mal didefinisikan sebagai institusi atau badan usaha yang mentadbir kekayaan negara sama ada berkenaan dengan pemasukan dan pentadbiran mahupun berkenaan dengan perkara pengagihan. Lihat Harun Nasution et al. (1992), Ensiklopedia Islam Indonesia. Jakarta: Djambatan, p. 161.

${ }^{17}$ Majalah Sharing edisi 47 Tahun V, November 2010 kemudian pemerintah mengundangkan UU No. 23 Tahun 1999 tentang Bank Indonesia (BI) yang dalam Pasal 10, menyatakan bahwa BI dapat menerapkan policy keuangan berdasarkan prinsipprinsip Syariah. ${ }^{18}$ Hadirnya 2 undangundang tersebut semakin memperkokoh landasan yuridis eksistensi bank Syariah di Indonesia. Selain mengatur bank Syariah, kedua UU tersebut menjadi landasan hukum bagi perbankan nasional untuk mulai melaksanakan dual banking system, yaitu sistem perbankan konvensional dan Syariah yang berjalan secara berdampingan, di mana bank konvensional yang telah ada dibolehkan membuka Syariah windows. Sejak itu, didirikan berbagai Unit Usaha Syariah (UUS) di bank konvensional seperti Bank IFI cabang usaha Syariah (1999), Bank Jabar cabang usaha Syariah (2000), Bank BNI 46 Syariah (2000), Bank Bukopin cabang usaha Syariah (2001), BRI Syariah (2001), Bank Danamon Syariah (2002), BII Syariah (2003) dan lain-lain. ${ }^{19}$ Di samping itu berdiri pula Bank Umum Syariah (BUS) seperti Bank Syariah Mandiri (BSM) yang sepenuhnya beroperasi secara Syariah (1999) dan Bank Syariah Mega Indonesia (2004).

Hingga Januari 2011, telah menjadi 11 BUS, 23 UUS, 151 BPRS dengan aset mencapai 95 Trilyun plus $745 \mathrm{M}$ (per Januari 2011). ${ }^{20}$

Perkembangan praktik ekonomi syariah dalam bidang asuransi Syariah di Indonesia dimulai sejak tahun 1994 yang

\footnotetext{
${ }^{18}$ Sutan Remy Sjahdeini (1999), Perbankan Islam dan Kedudukannya dalam Tata Hukum Perbankan Indonesia. Jakarta: Grafiti, h. 157.

${ }^{19}$ Sofyan S. Harahap dan Yuswar Z. Basri (2004), op.cit., h. 42. Lihat pula Muhammad Syafi' $i$ Antonio (2001), op.cit., h. 25-28. Lihat pula Heri Sudarsono (2004), op.cit., h. 28-30.

${ }^{20}$ Statistik Perbankan Syariah (Januari 2011), Jakarta: Direktorat Perbankan Syariah BI, p. 6
} 
ditandai dengan pendirian PT Asuransi Takaful Indonesia. Setelah itu, jasa asuransi yang dikelola berdasarkan prinsip syariah mulai dikembangkan baik oleh lembaga asuransi full syariah ataupun perusahaan asuransi yang mengembangkan divisi syariah. Keberadaan asuransi syariah didorong oleh anjuran adanya upaya-upaya menuju kepada perencanaan masa depan dengan sistem proteksi yang dikenal dalam mekanisme asuransi dan keyakinan sebagian masyarakat bahwa pengelolaan asuransi harus sejalan dengan kaidah dan prinsip syariah khususnya berkaitan dengan pengelolaan keuangan yang bebas riba, maysir dan gharar. Akhir 2007 terdapat 37 perusahaan asuransi syariah, 3 reasuransi syariah, 5 broker asuransi dan reasuransi Syariah. Menurut Biro Perasuransian Bapepam-LK pada tahun 2010 telah ada 45 lembaga asuransi syariah yang terdiri dari 42 perusahaan asuransi syariah dan 3 perusahaan re-asuransi syariah. $^{21}$

Perkembangan pegadaian Syariah di Indonesia yang tahun ini sudah memasuki tahun ke-10, sejak diluncurkan pada Januari 2003 juga menunjukkan kemajuan yang cukup menggembirakan. Perkembangan Pegadaian Syariah sampai akhir Februari 2009, jumlah pembiayaan mencapai $\mathrm{Rp} 1.6$ trilyun dengan jumlah nasabah 600 ribu orang; Jumlah kantor cabang berjumlah 120 buah. $^{22}$ Perkembangan yang menggembirakan juga terjadi di pasar modal. Berdasarkan Keputusan Nomor: Kep-523/BL/2010 tentang daftar efek Syariah, telah ditetapkan nama-nama efek yang sesuai dengan Syariah berjumlah 209 yang terdiri dari SBSN, saham, obligasi Syariah, dan

\footnotetext{
${ }^{21}$ http://www.pkesinteraktif.com/lifestyle/wa wancara-eksklusif/leasing-dan-asuransi-syariah/

${ }^{22}$ http://www.pegadaian.co.id/berita.php?
}

reksadana Syariah. ${ }^{23}$ Ini berarti semakin banyaklah efek yang dapat dipilih masyarakat untuk berinvestasi di pasar modal Syariah.

Secara spesifik, pemerintah Indonesia telah menerbitkan sukuk negara sebagai salah satu instrumen pembiayaan pemerintah, yaitu sukuk global, korporasi, dan sukuk ritel. Sukuk negara perdana yang dikeluarkan pemerintah Indonesia diterbitkan dengan tingkat imbalan tetap sebesar 8,8 persen dengan tenor lima tahun, sedangkan yang sukuk ritel bertenor 3 tahun dengan imbalan tetap sebesar 12 persen. Faktor utama yang mendasari penerbitan sukuk negara ini, yaitu sebagai instrumen diversifikasi pembiayaan defisit anggaran pemerintah dan percepatan akselerasi ekonomi syariah di Indonesia. ${ }^{24}$ Dalam hal lembaga bisnis Syariah, perkembangannya di Indonesia juga sangat pesat. Hal ini dapat dilihat dari munculnya berbagai perusahaan pembiayaan yang menawarkan jasa keuangan Syariah seperti FIF Syariah, alIjarah Indonesia Finance, dan lain-lain. Muncul juga bisnis sektor riil baik barang maupun jasa yang menerapkan prinsip Syariah seperti Sofyan Hotel, Ahad-Net internasional, dan lain-lain. ${ }^{25}$

Di samping itu, dalam sektor keuangan publik Islam juga telah berkembang lembaga-lembaga yang bonafid dan dibentuk pemerintah seperti BWI (Badan Wakaf Indonesia) dan BAZNAS (Badan Amil Zakat nasional) dan derivasinya sebagai pengejawantahan regulasi yang diundangkan pemerintah. Walaupun lembaga-lembaga tersebut

\footnotetext{
${ }^{23}$ http://www.bapepam.go.id/syariah/daftar_e fek_syariah/,

${ }^{24}$ Jaka Sriyana (2009), "Peranan Sukuk Negara Terhadap Peningkatan Fiscal Sustainability", Paper dalam Simposium Nasional Ekonomi syariah IV, 8-9 Oktober 2009 di Hotel Syahid Yogyakarta, ISBN 978-979-3333-36-6.

${ }^{25}$ www.mui.or.id,
} 
belum optimal menggali potensi dana wakaf, zakat, infak, dan sedekah dari masyarakat Indonesia yang memang potensinya sangat besar. Menurut Direktorat Pemberdayaan Zakat yang disampaikan dalam Lokakarya Peradaban Zakat di DIY, 7-9 April 2008 mencapai 39 trilium Rupiah per tahun. Angka ini hampir sama dengan hasil kajian Rumah Zakat pada tahun 2007. Padahal dari potensi yang sebegitu besar itu, baru 900 Miliar yang dapat dihimpun. Oleh karena itu, untuk menghimpun potensi dana wakaf, zakat, infak, dan sedekah yang ada di masyarakat Indonesia masih diperlukan upaya yang lebih canggih dengan dukungan sumber daya manusia (SDM) yang profesional. ${ }^{26}$ Dalam bidang akademis, beberapa universitas terkemuka di Indonesia juga giat mengembangkan kajian akademis tentang ekonomi syariah. Hal itu ditandai dengan banyaknya lembaga-lembaga pendidikan yang menawarkan program pendidikan formal maupun pelatihan dalam bidang Ekonomi syariah, Keuangan Islam dan Perbankan Syariah baik pada tingkat Sarjana (S1) maupun tingkat Pascasarjana (S2 dan S3).

Berdasarkan gambaran di atas, perkembangan dan pertumbuhan praktik ekonomi syariah di Indonesia, terutama di era reformasi memberikan harapan besar yang menumbuhkan optimisme bagi umat Islam untuk terus berupaya mengembangkan ekonomi syariah di Indonesia, terlebih lagi dukungan pemerintah yang diwujudkan dalam berbagai regulasi dan political will semakin nyata mendukung pengembangan ekonomi syariah di Indonesia.

\section{Legalisasi ekonomi Syariah di Era Reformasi}

${ }^{26}$ Direktorat Pemberdayaan Zakat dalam Lokakarya Peradaban Zakat di Hotel Ros In DIY, 7-9 April 2008.
Legalisasi Ekonomi Syariah Indonesia, pemerintah diimplementasikan dalam bentuk regulasi dan undang- undang mendorong perkembangan ekonomi syariah. Secara kebijakan ekonomi syariah, ada beberapa hal yang mengharuskan pemerintah melakukan dan membuat instrumen terhadap pengembangan ekonomi syariah, yaitu: (1) Industri keuangan syariah memiliki dampak yang positif bagi stabilitas perekonomian makro Indonesia, (2) Industri keuangan syariah memiliki ketahanan/ resistensi yang cukup tinggi terhadap goncangan krisis keuangan, (3) Diperlukannya peran aktif pemerintah sebagai regulator dan supervisor sehingga tercipta efisiensi, transparansi dan berkeadilan, (4) Ekonomi syariah dapat berperan sebagai penyelamat bila terjadi ketidakpastian usaha/perekonomian (5) Dalam teori maupun realitasnya, industri keuangan syariah membutuhkan infrastruktur yang mendukung perkembangannya. ${ }^{27}$ Dalam koridor itulah, kelembagaab ekonomi Syariah pada era reformasi dapat dipaparkan sebagai berikut:

\section{Dewan Syariah Nasional Majelis Ulama Indonesia (DSN MUI) Tahun 1999}

MUI sebagai lembaga yang memiliki kewenangan dalam bidang keagamaan yang berhubungan dengan kepentingan umat Islam Indonesia membentuk suatu dewan syariah yang berskala nasional yang bernama Dewan Syariah Nasional (DSN), berdiri pada tanggal 10 Februari 1999 sesuai dengan Surat Keputusan (SK) MUI No. kep-754/MUI/II/1999. Lembaga DSN

\footnotetext{
${ }^{27}$ Dahlan Siamat (2009), Intervensi Pemerintah Dalam Penguatan Sistem Keuangan Islam: Pengembangan Pasar Keuangan Syariah Merupakan Prioritas, Paper nara sumber dalam Simposium Nasional Ekonomi syariah IV, 8-9 Oktober 2009 di Hotel Syahid Yogyakarta, ISBN 978-979-3333-36-6.
} 
MUI ini merupakan lembaga yang memiliki otoritas kuat dalam penentuan dan penjagaan penerapan prinsip Syariah dalam operasional di lembaga keuangan Syariah, baik perbankan Syariah, asuransi Syariah dan lain-lain. Hal ini sebagaimana termuat dalam UU No.21 Tahun 2008 tentang Perbankan Syariah pasal 32 maupun UU No.40 Th 2007 tentang Perseroan Terbatas pasal 109 yang pada intinya bahwa Dewan Pengawas Syariah wajib dibentuk di bank Syariah maupun perseroan yang menjalankan kegiatan usaha berdasarkan prinsip syariah. Dewan Pengawas Syariah tersebut hanya dapat diangkat jika telah mendapatkan rekomendasi DSN MUI. Keberadaa ulama dalam stuktur kepengurusan perbankan maupun perseroan lainnya merupakan keunikan tersendiri bagi suatu lembaga bisnis. Para ulama yang berkompeten di bidang hukum syariah dan aplikasi perbankan dan perseroan yang menjalankan kegiatan usaha berdasarkan prinsip syariah memiliki fungsi dan peranan yang amat besar dalam penetapan dan pengawasan pelaksanaan prinsipprinsip syariah dalam lembaga bisnis. Kewenangan ulama dalam menetapkan dan mengawasi plaksanaan hukum perbankan syariah berada di bawah koordinasi Dewan Syariah Nasional majelis Ulama Indonesia (DSN-MUI). DSN adalah dewan yang dibentuk oleh MUI untuk menangani maslah-masalah yang berhubungan dengan aktivitas lembaga keuangan syariah. Sedangkan Dewan Pengawas Syariah (DPS) adalah badan yang ada di lembaga keuangan syariah dan bertugas mengawasi pelaksanaan keputusan DSN di lembaga keuangan syariah. DSN membantu pihak terkait seperti Departemen keuangan, Bank Indonesia, dan lain-lain dalam menyusun peraturan atau ketentuan untuk lembaga keuangan syariah. Keanggotaan DSN terdiri dari para ulama, praktisi, dan para pakar dalam bidang yang terkait dengan muamalah syariah. Keanggotaan DSN ditunjuk dan diangkat oleh MUI untuk masa bakti 4 tahun. Tugas dan kewenangan Dewan Syariah nasional adalah sebagai berikut: (a). Menumbuhkembangkan penerapan nilai-nilai syariah dalam kegiatan perekonomian pada umumnya dan keuangan pada khususnya. (b). Mengeluarkan fatwa atas jenis-jenis kegiatan keuangan. (c). Mengeluarkan fatwa atas produk dan jasa keuangan syariah. (d). Mengawasi penerapan fatwa yang telah dikeluarkan. Untuk dapat menjalankan tugas, Dewan Syariah Nasional memiliki kewenangan: (a). Mengeluarkan fatwa yang mengikat DPS di masing-masing lembaga keuangan syariah dan menjadi dasar tindakan hukum pihak terkait. (b). Mengeluarkan fatwa yang menjadi landasan bagi ketentuan atau peraturan yang dikeluarkan oleh instasi yang berwenang, seperti Departemen Keuangan dan Bank Indonesia. (c). Memberikan rekomendasi dan atau mencabut rekomendasi nama-nama yang akan duduk sebagai DPS pada suatu lembaga keuangan syariah. (d). Mengundang para ahli menjelaskan suatu masalah yang diperlukan dalam pembahasan ekonomi syariah, termasuk otoritas moneter atau lembaga keuangan dalam maupun luar negeri. (e). Memberikan peringatan kepada lembagalembaga keuangan syariah untuk menghentikan penyimpangan dari fatwa yang telah dikeluarkan oleh DSN. (f). Mengusulkan kepada instasi yang berwenang untuk mengambil tindakan apabila peringatan tidak diindahkan. Untuk memperkuat kewenangan sebagai bank sentral yang mengurusi sistem keuangan syariah dalam negara republik Indonesia, Bank Indonesia menjalin kerja sama dengan DSN-MUI yang memiliki otoritas di bidang hukum syariah. Bentuk kerja sama antara Bank Indonesia dengan DSNMUI diwujudkan melalui nota 
kesepahaman (Memorandum of Understanding/MOU) untuk menjalankan fungsi pembinaan dan pegawasan terhadap perbankan syariah. Dengan adanya kerja sama tersebut, berarti keberadaan DSNMUI menjadi sangat penting dalam pengembangan sistem ekonomi dan perbankan syariah negeri ini. ${ }^{28}$

2. UU No. 38 Tahun 1999 tentang Zakat Kemudian disempurnakan UU No 23 tahun 2011

Diundangkannya UU Zakat menunjukkan kebijakan ekonomi syariah dalam ranah keuangan publik pemerintah cukup akomodatif terhadap kebutuhan umat Islam untuk melaksanakan rukun Islam yang ke-3. Menurut Direktorat Pemberdayaan Zakat yang disampaikan dalam Lokakarya Peradaban Zakat di DIY, 7-9 April 2008 potensi zakat yang dapat dikumpulkan secara nasional mencapai 39 triliun Rupiah per tahun. Angka ini hampir sama dengan hasil kajian Rumah Zakat pada tahun 2007. Padahal dari potensi yang sebegitu besar itu, baru 1 triliun-an yang dapat dihimpun. Oleh karena itu, UU Zakat adalah kebutuhan umat Islam. Persoalannya, ternyata UU tersebut belum bisa berperan optimal untuk menarik zakat. Oleh karena itu perlu politik ekonomi syariah lanjutan, untuk lebih memikat muzakki, mestinya zakat yang semula hanya sebagai pengurang penghasilan kena pajak (PPKP) ${ }^{29}$ ditingkatkan menjadi pengurang pajak (tax deductible). Misalnya $\mathrm{PPh}$ terhadap penghasilan (profesi) di atas Rp. 50.000.000,00 s.d Rp. 250.000.000,00 adalah 15\% (Tarif PPh Pasal 17 UU PPh No 36 tahun 2008). Subyek pajaknya sudah membayar zakat sebesar 2,5\%, maka tinggal membayar Pajak kekuarangannya, yaitu $15 \%-2,5 \%=12,5 \%$. Dengan

\footnotetext{
${ }^{28}$ Himpunan Fatwa DSN, Edisi Kedua, diterbitkan atas kerjasama DSN-MUI dengan Bank Indonesia, h. 281-284; www.mui.or.id,.

${ }^{29}$ UU Pajak No. 17 Th.2000, Pasal 9 huruf g
}

demikian, fungsi zakat sebagai penghargaan (reward) terhadap pembayar pajak, menjadi lebih signifikan. Dengan kebijakan itu, meski pajak secara prosentase menjadi lebih kecil namun proyeksi total amount-nya akan lebih besar seiring besarnya semangat rakyat membayar pajak.

\section{UU No. 41 Tahun 2004 tentang Wakaf}

Untuk melengkapi Undang-undang tersebut, pemerintah juga telah menetapkan Peraturan Pemerintah Nomor 42 tahun 2006 tentang Pelaksanaan Undang-undang Nomor 41 tahun 2004, ditambah Kepmen Nomor 04 Tahun 2009 tentang Administrasi Wakaf Uang. Sebelum itu, telah ada berbagai peraturan yang mengatur tentang wakaf. ${ }^{30}$ Peraturan yang mengatur tentang wakaf adalah UU No. 5 Tahun 1960 tentang Peraturan Dasar Pokok-pokok Agraria, khususnya pasal 5, 14 (1), dan 49, PP No. 28 Tahun 1977 tentang Perwakafan Tanah Milik, Peraturan Menteri No. 1 Tahun 1978 tentang Peraturan Pelaksanaan PP No. 28 Tahun 1977, Intruksi Bersama Menag RI dan Kepala BPN No. 4 Tahun 1990 tentang Sertifikat Tanah Wakaf, Badan Pertanahan Nasional No. 630.1-2782 tantang Pelaksanaan Penyertifikatan Tanah Wakaf, Inpres No. 1 Tahun 1991 tentang KHI, SK Direktorat BI No. 32/34/KEP/DIR tentang Bank Umum Berdasarkan Prinsip Syariah (pasal 29 ayat 2 berbunyi: bank dapat bertindak sebagai lembaga baitul mal, yaitu menerim dana yang berasal dari zakat, infaq, shadaqah, wakaf, hibah, atau dana sosial lainnya dan menyalurkannya kepada yang berhak dalam bentuk santunan dan atau pinjaman kebajikan [qard al-hasan]), SK Direktorat BI No. 32/36/KEP/DIR tentang Bank Perkreditan Rakyat Berdasarkan Prinsip Syariah (pasal 28 berbunyi: BPRS dapat

${ }^{30}$ Lihat DEPAG RI, Peraturan Perundangan Perwakafan. (Jakarta: DEPAG RI, 2006) 
bertindak sebagai lembaga baitul mal, yaitu menerim dana yang berasal dari zakat, infaq, shadaqah, wakaf, hibah, atau dana social lainnya dan menyalurkannya kepada yang berhak dalam bentuk santunan dan atau pinjaman kebajikan [qard al-hasan]). ${ }^{31}$ Itu semua menunjukkan politik ekonomi syariah yang diperankan pemerintah RI dalam ranah keuangan publik Islam telah menunjukkan keberpihakannya pada penerapan keuangan publik Islam secara legal formal. Kalau begitu, sekarang tinggal action nya. Kalau dulu, banyak orang berdiskusi dan berharap adanya lembaga khusus yang menangani perwakafan di Indonesia, kini BWI (Badan Wakaf Indonesia) sudah berdiri (sejak 2007). Tinggal bagaimana memaksimalkan lembaga independen amanat undang-undang itu. ${ }^{32}$

\section{UU No. 3 Tahun 2006. Tentang Kewenangan Peradilan Agama \\ Diundangkannya Undang-undang} Nomor 3 Tahun 2006 tentang perubahan atas Undang-undang Nomor 7 Tahun 1989 tentang Peradilan Agama telah memberikan arah baru bagi kompetensi Peradilan Agama. Semula kompetensi Pengadilan Agama identik dengan NTCR (Nikah, Talak, Cerai dan Rujuk), akan tetapi dengan adanya UU Nomor 3 Tahun 2006 tersebut, kompetensi Peradilan Agama bertambah, khususnya sebagaimana yang tersebut dalam pasal 49 huruf i, yakni Pengadilan agama bertugas dan berwenang memeriksa, memutus, dan menyelesaikan perkara di tingkat pertama antara orang-orang yang beragama Islam di bidang ekonomi Syariah. Ekonomi Syariah yang dimaksud dalam pasal 49 huruf i,

\footnotetext{
${ }^{31}$ Elsi Kartika Sari, Pengantar Hukum Zakat dan Wakaf. (Jakarta: Grasindo, 2006), h. 57-59.

${ }^{32}$ Nur Kholis (2009), "Ikhtiar Memberdayakan Potensi Wakaf Secara Produktif di Indonesia", Paper dalam Simposium Nasional Ekonomi syariah IV, 8-9 Oktober 2009 di Hotel Syahid Yogyakarta, ISBN 978-979-3333-36-6.
}

penjelasannya mencakup (a) bank syari'ah; (b). lembaga keuangan mikro syari'ah. (c). asuransi syari'ah; (d). reasuransi syari'ah; (e). Reksa dana syari'ah; (f). obligasi syari'ah dan surat berharga berjangka menengah syari'ah; (g). sekuritas syari'ah; (h). pembiayaan syari'ah; (i). Pegadaian syari'ah; (j). dana pensiun lembaga keuangan syari'ah; dan (k). bisnis syari'ah. ${ }^{33}$ Salah satu pertimbangan diundangkannya UU Nomor 3 Tahun 2006, poin c adalah bahwa Peradilan Agama sebagaimana diatur dalam Undang-Undang Nomor 7 Tahun 1989 tentang Peradilan Agama sudah tidak sesuai lagi dengan perkembangan kebutuhan hukum masyarakat dan kehidupan ketatanegaraan menurut Undang-Undang Dasar Negara Republik Indonesia Tahun 1945. Hal ini memang sangat benar. Perkembangan kebutuhan hukum masyarakat tidak dapat dipenuhi dengan UU No. 7 Tahun 1989, terutama setelah tumbuh dan berkembangnya praktik ekonomi syariah di Indonesia.

Berdasarkan UU Nomor 3 Tahun 2006, peradilan yang berkompeten untuk menyelesaikan perkara di bidang ekonomi Syariah adalah pengadilan agama. Di samping itu, dibuka pula kemungkinan penyelesaian sengketa melalui musyawarah, mediasi perbankan, lembaga arbitrase, atau melalui pengadilan di lingkungan Peradilan Umum sepanjang disepakati di dalam akad oleh para pihak. Ketentuan ini juga memberikan kepastian saluran hukum bagi pencari keadilan dalam masalah yang timbul di bank Syariah. ${ }^{34}$

\section{UU Nomor 19 tahun 2008 tentang Surat Berharga Syariah Negara (SBSN).}

UU Nomor 19 tahun 2008 tentang Surat Berharga Syariah Negara (SBSN)

\footnotetext{
${ }^{33}$ Lihat penjelasan UU No. 3 Tahun 2006 pasal 49 huruf $\mathrm{i}$.

${ }^{34}$ UU No. 3 Tahun 2006 tentang tentang perubahan atas Undang-undang Nomor 7 Tahun 1989 tentang Peradilan Agama
} 
disahkan pada 7 Mei 2008. ${ }^{35}$ Lahirnya UU SBSN memberikan harapan di tengah APBN yang selalu defisit untuk bisa mendorong tersedianya sumber keuangan alternatif bagi negara. UU SBSN saat ini telah menjadi landasan hukum bagi pemerintah RI untuk penerbitan sukuk negara guna menarik dana dari investor. Sukuk dipandang sebagai alternatif yang lebih baik daripada berutang ke luar negeri karena antara lain mengandung unsur kerja sama investasi, berbagi risiko dan keterlibatan aset (proyek riil) yang juga mendasari penerbitan sukuk. ${ }^{36}$ Sukuk negara ada yang diterbitkan untuk investor besar (institusi) disebut IFR (ijara fixed rate) yang minimal pembeliannya 1 Miliar. Sedangkan untuk perorangan (ritel) disebut Sukuk Ritel (SR) yang diterbitkan setiap Februari. Hingga tahun 2011 ini telah diterbitkan 3 seri SR. Tujuan utama pemerintah menerbitkan sukuk negara adalah untuk membiayai APBN, termasuk membiayai pembangunan proyek. Ini menunjukkan dukungan pemerintah untuk mendanai APBN dengan instrumen keuangan Syariah, dan terbukti perkembangan sukuk global maupun ritel sangat pesat setelah ada political will pemerintah dengan mengesahkan UU SBSN.

\section{UU No. 21 Tahun 2008 tentang Perbankan Syariah}

Pada 17 Juni 2008 telah diundangkan UU No. 21 Tahun 2008 tentang Perbankan Syariah. Lahirnya UU Perbankan Syariah menandai era baru perbankan Syariah berpayung hukum jelas. Dengan UU Perbankan Syariah ini makin memperkuat landasan hukum perbankan Syariah sehingga dapat setara dengan bank konvensional. Selain itu, payung hukum ini

\footnotetext{
${ }^{35}$ Republika, 18 Juni 2008

${ }^{36}$ Rifki Ismal \& Khairunnisa Musari. (2009b). Menggagas Sukuk sebagai Instrumen Fiskal dan Moneter. Bisnis Indonesia. 1 April.
}

makin menguatkan eksistensi perbankan syariah di Indonesia dan juga dapat makin memacu peningkatan peran dan kontribusi perbankan syariah dalam mengentaskan kemiskinan (poverty alleviation), kesejahteraan masyarakat, dan pembukaan lapangan kerja serta pembangunan nasional.

Perlu digarisbawahi bahwa perkembangan pesat perbankan syariah tidak bisa dilepaskan dari dukungan regulasi. Kehadiran bank syariah pertama pada 1992, yaitu Bank Muamalat Indonesia, terjadi berkat dukungan Undang-undang Nomor 7 Tahun 1992. Booming perbankan syariah sejak 1999 juga hasil dari dukungan regulasi, yaitu Undang-undang Nomor 10 Tahun 1998 dan Undang-undang Nomor 23 Tahun 1999 yang kemudian diperkuat oleh UU Nomor 3 Tahun 2004. Setelah diundangkannya UU Perbankan Syariah terjadi akselerasi perkembangan perbankan Syariah yang dibuktikan bahwa pada Januari 2011, jumlah bank Syariah telah menjadi 11 BUS, 23 UUS, 151 BPRS dengan aset mencapai 95 Trilyun plus 745 M (per Januari 2011) ${ }^{37}$, padahal sebelumnya hanya ada 3 BUS saja dengan total aset $48 \mathrm{~T}$ plus $82 \mathrm{M}^{38}$

\section{Peraturan Mahkamah Agung (Perma) 02 Tahun 2008 Khes (Kompilasi Hukum Ekonomi Syari'ah)}

Penyusunan Kompilasi Hukum Ekonomi Syari'ah (KHES) yang dikordinir oleh Mahkamah Agung (MA) RI yang kemudian dilegalkan dalam bentuk PERATURAN MAHKAMAH AGUNG (PERMA) 02 Tahun 2008 merupakan respon terhadap perkembangan baru dalam

${ }^{37}$ Statistik Perbankan Syariah (Januari 2011), Jakarta: Direktorat Perbankan Syariah BI, p. 6

${ }^{38}$ Statistik Perbankan Syariah (Mei 2008), Jakarta: Direktorat Perbankan Syariah BI, pp. 2-3 
kajian dan praktek ekonomi syariah di Indonesia. Praktik hukum ekonomi syariah secara institusional di Indonesia itu sudah dimulai sejak berdirinya Bank Muamalat Indonesia (BMI) pada tahun 1991, kemudian disusul oleh lembaga keuangan syari'ah (LKS) lainnya setelah melihat prospek dan ketangguhan LKS seperti BMI ketika melewati krisis ekonomi nasional sekitar tahun 1998. Belakangan, perkembangan LKS tersebut semakin pesat yang tentu akan menggambarkan banyaknya praktek hukum muamalat di kalangan umat Islam.

Banyaknya praktek hukum tersebut juga sarat dengan berbagai permasalahan yang muncul akibat dari tarik menarik antar kepentingan para pihak dalam persoalan ekonomi, sementara untuk saat ini belum ada peraturan perundangundangan yang mengatur secara khusus terhadap permasalahan itu. Sejak tahun 1994, jika ada sengketa ekonomi syariah maka diselesaikan lewat Badan Arbitrase Syariah Nasional (Basyarnas) yang hanya sebagai mediator (penengah) dan belum mengikat secara hukum. Peraturan yang diterapkan juga masih terbatas pada peraturan Bank Indonesia (BI) yang merujuk kepada fatwa-fatwa Dewan Syari'ah Nasional Majelis Ulama Indonesia (DSN-MUI). Sedangkan fatwa itu, sebagaimana dimaklumi dalam hukum Islam, adalah pendapat hukum yang tidak mengikat seluruh umat Islam. Sama halnya dengan fikih.

Kehadiran KHES merupakan bagian upaya positifisasi hukum perdata Islam dalam sistem hukum nasional. Untuk saat ini positifisasi hukum ekonomi syariah sudah menjadi keniscayaan bagi umat Islam, mengingat praktek ekonomi syari'ah sudah semakin semarak melalui LKS-LKS. Kompilasi tersebut kemudian dijadikan acuan dalam penyelesaian perkara-perkara ekonomi syari'ah yang semakin hari semakin bertambah, seiring dengan perkembangan LKS. Adapun lembaga peradilan yang berkompetensi dalam penerapan KHES adalah Peradilan Agama (PA) sebagaimana diamanatkan UU No. 3 Tahun 2006.

\section{PP Nomor 39 Tahun 2008 Asuransi syariah}

Tentang Perubahan Kedua Atas Peraturan Pemerintah Nomor 73 Tahun 1992 tentang Penyelenggaraan Usaha Perasuransian. Walaupun pemerintah belum mengundangkan secara khusus tentang asuransi Syariah, akan tetapi hadirnya PP Nomor 39 tersebut menunjukkan keberpihakan pemerintah terhadap pengembangan industri asuransi Syariah sebagai bagian politik ekonomi syariahnya.

\section{Direktorat pembiayaan Syariah di DEPKEU}

Direktorat Pembiayaan Syariah, Direktorat Jenderal Pengelolaan Utang Departemen Keuangan RI merupakan direktorat yang melaksanakan amanah UU No. 19 Tahun 2008 tentang SBSN, sehingga lahirnya berbagai jenis sukuk negara, di antaranya adalah sukuk ritel dan korporasi. $^{39}$

\section{UU 23 tahun 2011 tentang Zakat}

Undang-Undang No. 38 tahun 1999

(UU zakat lama) telah berlaku selama 12 tahun. UU No.38 tahun 1999 ini dinilai memiliki banyak kekurangan dan amat ringkas. UU No. 38 tahun 1999 juga tidak memiliki Peraturan Pemerintah, karena UU tersebut hanya menyebutkan bahwa aturan turunannya diatur dalam peraturan menteri. Sudah lama dirasakan dan diusulkan agar UU No. 38 tahun 1999 itu diamandemen atau direvisi. Gagasan awal yang banyak mengemuka terkait upaya revisi UU zakat lama adalah: 1) adanya sanksi bagi

\footnotetext{
${ }^{39}$ Dahlan Siamat (2009), Intervensi Pemerintah Dalam Penguatan Sistem Keuangan Islam: Pengembangan Pasar Keuangan Syariah Merupakan Prioritas, Paper nara sumber dalam Simposium Nasional Ekonomi syariah IV, 8-9 Oktober 2009 di Hotel Syahid Yogyakarta, ISBN 978-979-3333-36-6.
} 
muzakki yang ingkar, baik sanksi administrasi maupun sanksi finansial 2) Penataan organisasi pengelola zakat dan pemisahan fungsi regulator atau pengawas, operator dan kordinator, serta 3) menjadikan Zakat sebagai pengurang pajak (menurut UU 38/ 1999 : zakat sebagai pengurang penghasilan kena pajak). Proses penyusunan UU zakat baru sudah berlangsung cukup lama. Pembahasannya sudah dimulai sejak DPR periode 20042009. Karena belum selesai pembahasan UU zakat baru ini harus dilimpahkan kepada DPR periode 2009-2014. Pembahasan pada DPR Periode 2009-2012 berlangsung hampir selama 2 tahun. Dalam pembahasan tersebut telah mengalami beberapa kali perubahan konsep dan tarik menarik kepentingan yang sangat kuat. Dalam UU No. 23 tahun 2011 yang disahkan pada tanggal 27 oktober 2011 terdapat 11 Bab dan 47 Pasal. Muatan inti yang terkandung dalam UU Zakat baru tersebut adalah : 1) Pengelolaan zakat menjadi kewenangan negara, masyarakat hanya diperkenankan ikut mengelola apabila ada izin dari pemerintah. 2) Pengelolaan zakat dilakukan oleh BAZNAS yang beroperasi dari tingkat pusat sampai kab/kota secara hirarkis (untuk selanjutnya BAZNAS dapat membentuk UPZ). 3) Anggota BAZNAS terdiri delapan orang perwakilan masyarakat dan tiga orang perwakilan pemerintah. Perwakilan masyarakat terdiri dari ulama, tenaga profesional dan tokoh masyarakat, sedangkan perwakilan pemerintah dari unsur kementerian terkait. 4) LAZ berperan membantu BAZNAS dalam pengelolaan zakat (untuk selanjutnya LAZ dapat membentuk perwakilan). UU No. 23 tahun 2011 secara tersirat mengakomodasi keberadaan LAZ daerah. LAZ selain ditingkat nasional, juga dimungkinkan berdiri sebagai LAZ Provinsi dan LAZ Kab/Kota berdasarkan kandungan isi pasal 29 ayat 3 yang berbunyi: LAZ wajib menyampaikan laporan pelaksanaan pengelolaan zakat, infak, sedekah, dan dana sosial keagamaan lainnya kepada BAZNAS dan pemerintah daerah secara berkala Juga tersirat pada Pasal 34 ayat 2: Gubernur dan Bupati/Walikota melaksanakan pembinaan dan pengawasan terhadap BAZNAS provinsi, BAZNAS kabupaten/kota, dan LAZ sesuai dengan kewenangannya Pasal Mencemaskan Di dalam UU No. 23 Tahun 2011 terdapat pasal-pasal yang mencemaskan, yaitu : 1) Pasal 15 tentang pembentukan BAZNAS di propinsi dan kab/kota yang cenderung tidak lagi mengakui kewenangan Gubernur dan Bupati/Walikota. 2) Pasal 18 tentang persyaratan pemberian izin bagi LAZ yang mempersyaratkan harus berasal dari organisasi kemasyarakat Islam. 3) Pasal 29 tentang mekanisme "kordinasi" BAZNAS dan BAZNAS Provinsi, BAZNAS $\mathrm{Kab} /$ Kota serta antara BAZNAS dan LAZ. 4)Pasal 38 dan pasal 41 tentang ancaman sanksi bagi masyarakat yang mengelola zakat tapi tidak memiliki izin dari pemerintah. Pasal-pasal tersebut, jika penjelasan dan petunjuk pelaksanaannya tidak jelas, bisa berakibat menjadi kontra produktif dan mematikan sebagian potensi perkembangan zakat yang sudah baik selama ini. Pada Ketentuan Peralihan (pasal 43) UU zakat baru ini BAZNAS, BAZ Propinsi, dan BAZ Kab/Kota yang sudah ada sebelum UU zakat ini tetap berlaku dan dinyatakan sebagai BAZNAS Pusat, BAZNAS Propinsi dan BAZNAS Kab/kota. LAZ yang telah dikukuhkan oleh Menteri sebelum undang-undang ini berlaku dinyatakan sebagai LAZ berdasarkan Undang-Undang ini. LAZ sebagaimana dimaksud pada ayat (3) wajib menyesuaikan diri paling lambat 5 (lima) tahun terhitung sejak Undang-Undang ini diundangkan.

\section{UU No.33 Tahun 2014 Tentang Jaminan Produk Halal}


Hadirnya pemerintah dalam rangka melindungi penduduknya dalam rangka mendapatkan produk halal terwujud dengan disahkannya UU No.33 Tahun 2014 tentang Jaminan Produk Halal. ${ }^{40}$ Regulasi yang merumuskan perlindungan konsumen terkait kehalalan produk sebenarnya sudah diatur dalam UU Nomor 8 Tahun 1999 tentang Perlindungan Konsumen dan PP Nomor 69 Tahun 1999 tentang Label dan Iklan Pangan. Adapun regulasi terkait tata cara pencantuman tulisan halal pada label makanan diatur melalui Keputusan Dirjen POM Nomor HK. 00..06.3.00568. ${ }^{41}$ Namun, hadirnya beberapa regulasi tersebut dianggap belum cukup untuk memenuhi kebutuhan dan hak-hak dasar konsumen untuk mendapatkan produk halal. Regulasi tersebut hanya mengatur tentang kewajiban produsen untuk memeriksakan kehalalan produknya tanpa diatur lebih lanjut mengenai pengawasan serta implikasi hukum lebih lanjut terkait jaminan produk halal. Berbagai peraturan yang telah ada tersebut memang menyinggung mengenai JPH, namun dinilai masih bersifat ambiguous (Nidya Waras Sayekti:194). Setelah UU JPH ditetapkan, sistem penyelenggaraan JPH di Indonesia akan mengalami perubahan. Sertifikat halal bagi produk yang masuk, beredar, dan diperdagangkan di wilayah Indonesia ini sifatnya wajib. Hal ini sesuai dengan Pasal

\footnotetext{
${ }^{40}$ Sebelum disahkannya UU JPH, system jaminan halal di Indonesia dilakukan oleh MUI melalui LPPOM MUI. Sistem jaminan halal oleh LPPOM MUI berjalan kurang lebih 25 tahun. System jaminan halal yang diberlakukan oleh LPPOM MUI masih bersifat mandatory dan tidak mempunyai kekuatan hukum, hal ini dikarenakan tidak adanya paying hukum yang menaunginya.

${ }^{41}$ Istikomah, "Peluang Dan Tantangan Implementasi Uu Jph (Studi Analisis Atas Uu No. 33 Tentang Jaminan Produk Halal)," At-Tasharruf; Jurnal Kajian Ekonomi Dan Bisnis Syariah 1, no. 1 (2019): 18-28.
}

4 UU JPH yang berbunyi : "Produk yang masuk, beredar, dan diperdagangkan di wilayah Indonesia wajib bersertifikat halal" Pasal ini memberikan implikasi hukum bahwa seluruh produsen yang memperdagangkan produknya di wilayah Indonesia wajib mendaftarkan produknya untuk mendapatkan sertifikasi halal (baik produk tersebut berupa makanan, minuman, obat-obatan, kosmetik, farmastik maupun produk teknologi dan elektronik seperti mobil sepeda motor, handphone, dan lain sebagainya).

\section{E. Penutup}

Berdasarkan pemaparan di atas, perkembangan dan legalisasi ekonomi Syariah di Indonesia dapat dikatakan sangat pesat setelah mendapat dukungan pemerintah dalam bentuk regulasi ekonomi yang berprinsipkan pada prinsip-prinsip ekonomi syariah. Perkembangan pesat tersebut dapat terlihat dalam berbagai bidang ekonomi yang menerapkan sistem ekonomi syariah, seperti perbankan Syariah, asuransi Syariah, sukuk ( Obligasi syariah), pasar modal Syariah, keuangan publik, dan lain-lain. Fakta berbeda perkembangan dan pertumbuhan praktik ekonomi syariah dapat dilihat dalam kurun waktu di mana pemerintah belum berpihak pada ekonomi syariah, yaitu sebelum reformasi.

Realitas yang demikian, memberikan harapan besar yang menumbuhkan optimisme bagi umat Islam untuk terus berupaya mengembangkan ekonomi syariah di Indonesia, terlebih lagi dukungan pemerintah yang diwujudkan dalam berbagai regulasi dan political will semakin nyata mendukung pengembangan ekonomi syariah di Indonesia. Ke depan, pemerintah perlu terus didorong untuk menerapkan politik ekonomi yang berorientasikan pada sistem ekonomi syariah, misalnya zakat yang semula hanya sebagai pengurang penghasilan kena pajak 
(PPKP) ditingkatkan menjadi pengurang pajak (tax deductible), mengkonversi bank BUMN menjadi bank Syariah agar market share bank Syariah meningkat pesat, pemberdayaan UMKM dan potensi umat dan lain-lain. Diharapkan penerapan politik ekonomi syariah yang lebih luas akan mempercepat terwujudnya tatanan ekonomi yang berkeadilan dan menyejahterakan di bumi nusantara. Sehingga apa yang dicita- citakan oleh para pendiri bangsa bisa terwujud, Amin

\section{DAFTAR PUSTAKA}

Abdullah, Taufik (ed.), 1982. Agama, Etos Kerja dan Perkembangan Ekonomi. Jakarta: LP3ES

Abdul Aziz Thaba (1996), Islam dan Negara dalam Politik Orde Baru, Jakarta: Gema Insani Press.

Adiwarman Karim (2004), Bank Islam, Analisis Fiqh dan Keuangan. Jakarta: PT RajaGrafindo Persada

Bahtiar Effendy (1998), Islam dan Negara: Transformasi Pemikiran dan Praktik Politik Islam di Indonesia. Jakarta: Paramadina.

Dahlan Siamat (2009), Intervensi Pemerintah Dalam Penguatan Sistem Keuangan Islam: Pengembangan Pasar Keuangan Syariah Merupakan Prioritas, Paper nara sumber dalam Simposium Nasional Ekonomi syariah IV, 8-9 Oktober 2009 di Hotel Syahid Yogyakarta

DEPAG RI, Peraturan Perundangan Perwakafan. (Jakarta: DEPAG RI, 2006

Direktorat Pemberdayaan Zakat dalam Lokakarya Peradaban Zakat di Hotel Ros In DIY, 7-9 April 2008.

Elsi Kartika Sari, Pengantar Hukum Zakat dan Wakaf. (Jakarta: Grasindo, 2006)
Harun Nasution et al. (1992), Ensiklopedia Islam Indonesia. Jakarta: Djambatan

Himpunan Fatwa DSN, Edisi Kedua, diterbitkan atas kerjasama DSN-MUI dengan Bank Indonesia

Hasan Al Banna, Risalah Pergerakan, (Jakarta:Intermedia.1997)

Heri Sudarsono (2004), Bank dan Lembaga Keuangan Syariah; Deskripsi dan Ilustrasi. Yogyakarta: EKONISIA

http://www.antaranews.com/berita/126292 0334/presiden-canangkan-gerakanwakaf-uang, diakses pada 6 Maret 2011.

http://www.dakwatuna.com/ .

http://www.detiknews.com/ .

http://www.indonesia.go.id/id/ .

http://www.pkesinteraktif.com/lifestyle/wa wancara-eksklusif/leasing-danasuransi-syariah/,

http://www.pegadaian.co.id/berita.php? , http://www.bapepam.go.id/syariah/daftar_e fek_syariah/,

http://www.uccb.ns.ca/mchoudhu/ipe.htm, Imam Al Ghazali, Ihya Ulumuddin: Jilid 2, Asy Syifa, Jakarta, 1990.

Iman Hilman (2003), “Transformasi Perbankan Syariah, Suatu Keharusan", dalam Irwan Kelana et al. (eds.), Perbankan Syariah Masa Depan. Jakarta: PT Senayan Abadi.

Istikomah. "Peluang Dan Tantangan Implementasi Uu Jph (Studi Analisis Atas Uu No. 33 Tentang Jaminan Produk Halal)." At-Tasharruf; Jurnal Kajian Ekonomi Dan Bisnis Syariah 1, no. 1 (2019): 18-28.

Jaka Sriyana (2009), "Peranan Sukuk Negara Terhadap Peningkatan Fiscal Sustainability", Paper dalam Simposium Nasional Ekonomi syariah IV, 8-9 Oktober 2009 di Hotel Syahid Yogyakarta, ISBN 978979-3333-36-6.

M. Dawam Rahardjo (2004), "Menegakkan Syariat Islam 
di Bidang Ekonomi", kata pengantar Buku Adiwarman Karim, Bank Islam, Analisis Fiqh dan Keuangan. Jakarta: PT RajaGrafindo Persada

Mubyarto dkk.1991. Etos Kerja dan Kohesi Sosial. (Yogyakarta: Aditya Media).

Majalah Sharing edisi 47 Tahun V, November 2010

Muhammad Amin Suma (2003), "Jaminan Perundang-undangan Tentang Eksistensi Lembaga Keuangan Syariah di Indonesia", Jurnal alMawarid, Edisi X, p. 9.

Muhammad Syafi'i Antonio (2001), Bank Islam dari Teori ke Praktek. Jakarta: Gema Insani Press

Munawir Sjadzali (1990), Islam dan Tata Negara. Jakarta: Penerbit UI

Nur Kholis (2009), "Ikhtiar Memberdayakan Potensi Wakaf Secara Produktif di Indonesia", Paper dalam Simposium Nasional Ekonomi syariah IV, 8-9 Oktober 2009 di Hotel Syahid Yogyakarta, ISBN 978-979-3333-36-6.

Republika, 18 Juni 2008

Rifki Ismal \& Khairunnisa Musari. (2009b). Menggagas Sukuk sebagai Instrumen Fiskal dan Moneter. Bisnis Indonesia. 1 April.

Saad al-Harran (1995), Leading Issues in Islamic Banking and Finance. Selangor: Pelanduk Publication Sdn. Bhd.

Sofyan S. Harahap dan Yuswar Z. Basri (2004), "The History and
Development of Islamic Banking in Indonesia, 1990-2002", dalam Bala Shanmugan et al. (eds.), Islamic Banking: An International Perspective. Serdang: Universti Putra Malaysia Press.

Statistik Perbankan Syariah (2003), Jakarta: Biro Perbankan Syariah BI

Statistik Perbankan Syariah (Mei 2008), Jakarta: Direktorat Perbankan Syariah BI

Statistik Perbankan Syariah (Januari 2011), Jakarta: Direktorat Perbankan Syariah BI

Sutan Remy Sjahdeini (1999), Perbankan Islam dan Kedudukannya dalam Tata Hukum Perbankan Indonesia. Jakarta: Grafiti

UU Pajak No. 17 Th. 2000

Yusuf Qardhawi, Peran Nilai dan Moral dalam Perekonomian Islam, (Jakarta:Robbani Press. 2001) 
